\title{
Health Inequity at The Local Level: Theoretical Aspects and The Experience of Stavropol
}

\author{
Karen Amlaev* \\ Department of Public Health Stavropol State Medical University Stavropol, Russia \\ *Corresponding author: kum672002@mail.ru
}

Received February 28, 2014; Revised June 10, 2014; Accepted June 22, 2014

\begin{abstract}
The article describes the state of the problem of inequality in health in the world. The main causes of increasing inequality in health. The authors refer to them economic differentiation of society, the transition from health to the health of clinical medicine, unequal access to health services. Analyzed the influence of socioeconomic determinants that shape inequality in health. As the most important factors are considered poverty, ecological trouble, lack of education. Shown that lifestyle residents largely confined to socio economic factors that do not depend directly on the person. 2. This article discusses the concept of adherence and compliance of patients. We describe the pharmacological, clinical, and physical methods for assessing adherence. Factors affecting patient compliance, which include sex and age; characterological features of the patient, low education, level of will power, lack of education and intelligence, characteristics of the disease, the correct choice of the drug: it is fast enough and good efficacy and good tolerability; treatment regimen, the presence of drugs prescribed by your doctor pharmacies. 3. The article describes the situation with health literacy. The article describes the state of the problem of inequality in health in the world. The main causes of increasing inequality in health. The authors refer to them economic differentiation of society, the transition from health to the health of clinical medicine, unequal access to health services. Analyzed the influence of socio-economic determinants that shape inequality in health. As the most important factors are considered poverty, ecological trouble, lack of education. Shown that lifestyle residents largely confined to socio economic factors that do not depend directly on the person. The facts of correlation of health literacy to self-assessment of their own health, with personal income, economic growth, empowerment of women, life expectancy were presented. A review of effective European strategies for improving health literacy was done.
\end{abstract}

Keywords: health inequity, treatment compliance, health literacy

Cite This Article: Karen Amlaev, "Health Inequity at The Local Level: Theoretical Aspects and The Experience of Stavropol." American Journal of Public Health Research, vol. 2, no. 4 (2014): 136-146. doi: 10.12691/ajphr-2-4-3.

\section{Introduction}

The project Healthy Cities has been making its contribution to health promotion in the European Region for several decades now. The peculiar feature of it is proper response to the issues arising in public health and healthcare systems in European countries. This is reflected in the topics that are taken as key ones at certain stages of the Healthy Cities project.

The Russian Federation has been an active member of the European network of Healthy Cities and dozens of Russian cities have joined our movement in the latest years.

The article presented here focuses on relevant issues of modern healthcare - health inequity.

Health inequity has become one of the key priorities for the European Strategy 2020. Even though the health status indicators, such as the death rate, are improving all over Europe there are still sharp health differences between countries, inside countries, and even between cities and social groups. Unfortunately, health inequity is increasing the global economic recession being among the key causes here. The growing unemployment and cut budgets on public needs will affect millions of people's living conditions in Europe, and will have the greatest impact on the health status of the most vulnerable groups. Should there be no timely and proper measures taken this health inequity may only increase.

This entire range of issues with their potential solution is reflected in this article. The book offers a theoretical overview of the current state of the issue as well as provides the author's own findings and the experience of the City of Stavropol gained due to the participation in the Healthy Cities project.

\section{Health Inequity: The Current State}

\subsection{Health Inequity: Political and Social Aspects}

Literature will often use the term HEALTH INEQUITY as a synonym to HEALTH INJUSTICE. However, these terms are not similar. Since health inequity is a general 
term typically used to define differences, changes, and disproportions in the health status of individuals and groups not any health inequity will be unjust. Yet, many types of health inequity are undoubtedly unjust as the concept of health injustice focuses on distribution of resources and other processes that drive certain types of health inequity, i.e. on systematic disparities in terms of health (or in its social determinants) among various social groups enjoying more or less favorable opportunities. In other words it focuses on health inequities that are unjust and unfair.

Speaking of the English terms "inequality" and "inequity" that are used to define "disparity": in healthcare the expression social inequalities in health imply the same disparity [just like social inequities in health], which is unfair and unjust” (Whitehead and Dahlgren, 2008).

Some researchers suggest a definition based on which unfairness in health will be related to those health disparities that are considered avoidable, removable, unfair and unjust (Braveman P. et al, 1996, 2001; Newton K., 1997; Anand S., 2002; Whitehead and Dahlgren, 2008).

Health inequity is increasing both inside countries and among them. Besides, in all countries there is a large gap in terms of health status dividing various groups irrespective of their income. In high income countries there can be observed a more than 10-year life expectancy gap between various groups depending on such factors as the ethnicity, gender, social \& economic status, and the geography of residence. In poor countries all regions show significant difference in child death rate depending on the household welfare.

Health inequity means that a significant part of the society has no chance to reach their full health potential, and this cuts them from access and a chance to enjoy other basic human rights. The conclusion here implies that the society should be equal and fair in distributing the resources available so that to make these accessible for everyone (Whitehead, M. et al., 2008).

The findings from a number of European research projects suggest that the death rate among those found at the "lowest" rank of the social ladder is typically 2-3 times as high, while the life expectancy in non-qualified employees is 5 years shorter if compared with qualified personnel; also there is a 9-12-year gap between the poor and the well-off in terms of their life expectancy free from any disabling condition (Anand, 2002; Mackenbach, Kunst, 1997; Marmot, 2004).

Studying social inequity in health and its change over time is one of the key areas in the modern research into the sociology of health. Such research will help deeper comprehension of social mechanisms in the development of health and how much health inequity is due to economic and social changes that the society faces; this will also bring about the idea of the trends - either increasing or decreasing - in health inequity between different social groups. Such research projects are of great importance in terms of developing a social policy aiming at better public health, as well as of assessing the efficiency of the currently implemented measures (Anand, 2002; Mackenbach, Kunst, 1997; Marmot, 2004). According to the documents of the leading international organizations (World Health Organization, WHO, 1990; Braveman, Pitarino, Creese, and Monash, 1996) the nowadays policy of public healthcare is based on the concept of health as a specific public benefit the access to which should be determined following the principles of social justice. This implies equal opportunities in getting the key health resources for people representing various social groups. The implementation of this requirement would involve special attention towards the groups whose status is less favorable compared to others (Anand, 2002).

Mention should be made here that a policy aimed at reducing the health-related burden in low-status social groups will not just meet the justice principles, yet it will also contribute to significant improvement in the population's health in general (Mackenbach, and Kunst, 1997).

Even though the latest decade has seen measures to reduce inequity taken across Europe, there are still many countries with a growing concern that the disparities and inequities are expanding, which is especially obvious in the Central and Eastern Europe where the phenomena in question have adopted in this century an unprecedented scale if compared with other industrial countries. In some countries (the Russian Federation being one of them) where the worsening general health status in people is a common fact, the increasing inequity and disparities are a dramatic consequence of severe socio-economic shock. However, even countries with a good state of things in healthcare (e.g. Denmark, the Netherlands, and Sweden) also demonstrate significant evidence of retaining and even increasing inequity, which puts them, too, among the top concern objects from the point of view of public healthcare.

The range of socio-economic inequities is wide: gender- and age-related, educational, race-ethnic, professional, power-related, material- and property-related, territorial, etc. And way, socio-economic inequities violate the principle of social justice. In this respect the concept of social justice could be analyzed.

Social inequity has existed for the entire comprehensible human history. Even though inequity has always been subject to destructive criticism and has never been approved, yet people through history have demonstrated extreme resistance to any "ideal" society based on social equity and absence of suppression among groups.

There is special concern over social inequity when it comes to children's health. During that the report on health inequity, including the issues of qualitative assessment of gender, age, geographic, and socioeconomic factors influencing health disparities, contains data on the health status of adolescents aged 11, 13, and 15 in 2005-2006 representing 41 countries and the WHO's European region and North America. The purpose of the report was to detect the actual differences in youngsters' health status, and provision of information that could be useful for the development and implementation of specific programs, also contributing to improving young people's health at large.

This research has produced convincing evidence showing that despite the high health status and well-being in young people many of them still have severe issues related to overweight and obesity, low self-esteem, dissatisfaction with their life, and substance abuse (Whitehead M., Dahlgren G., 2008). 
The World Health Organization has developed an ambitious program Health for All, which targets at a $25 \%$ reduction of health inequities both inside countries and among them by the beginning of the XXI century (World Health Organization, Targets for Health for All, 1990). However, given the results obtained from numerous research projects the WHO European Bureau once again has defined the European targets for health inequity reduction.

HEALTH-21: European target 1 - Solidarity for health in the European Region.

By the year 2020, the present gap in health status between member states of the European region should be reduced by at least one third.

HEALTH-21: European target 2 - Equity in health.

By the year 2020, the health gap between socioeconomic groups within countries should be reduced by at least one fourth in all member states, by substantially improving the level of health of disadvantaged groups.

HEALTH-21: European target 3 - Multisectoral responsibility for health.

By the year 2020, all sectors should have recognized and accepted their responsibility for health (Whitehead and Dahlgren, 2008).

Prior to dealing with the prominent health inequity there should be an understanding of its major causes and health inequity manifestations.

Complete and proper understanding of how inequity develops - be that in terms of income or health - as well as what factors influence the process, how these inequities are related, and finding ways to reduce the inequity down to a socially acceptable level - all these are important premises for the development of an efficient socioесonomic policy (Кислицына О. А., 2005).

The most vulnerable to inequity groups still remain the youth, women, retirees, and low-qualification workers. Along with poverty and beggary (sometimes referred to as deep poverty) there is also disadvantage. This typically affects children, the disabled, retirees, representatives of another race or ethnicity, and the chronically poor.

A society may eliminate absolute poverty, yet there is always some relative. This is because inequity will inevitably accompany complex societies. Therefore, relative poverty will always be present even if the living standards for all the groups of a society have gone up.

The relation between the death rate and the income, the likelihood of a shorter life expectancy develops due to long accumulation of negative impacts from financial hardships and the emotional reactions linked to them. An individual's health status is largely determined by the social group this particular person belongs to. A preliminary analysis of the relation between health inequity and economic status shows that towards various health indicators there is both inverse (higher status fewer diseases) and direct relation. The position held by an individual in the social hierarchy - no matter how it may be defined - through job, level of education or income is always the determining factor both for the health status, and for the prevalence of behaviors that are destructive for health. The issue of social determination of health has been widely discussed by Russian authors (Назарова И. Б., 2007; Русинова Н. Л., Браун Дж., 1997; Журавлева И.В., 1999, 2006; Русинова Н. Л., Панова Л.В. Сафронов В.В., 2007).
They showed in their research that people employed in areas with lower status and low income more often demonstrate stress symptoms. Stress can act as an effect modifier. This means that in case of comparable levels of harmful impacts those experiencing stress are more susceptible to diseases and accidents. We should also keep in view the extra effects of behavioral stress manifestations, such as smoking, alcohol abuse or violence.

An empirical illustration of interrelation between health inequity and income inequity is, for instance, the data on differentiation of the medium number of health deviations in various groups of subjective economic status. The highest number of health issues has been registered in the groups with the lowest economic status, and the number will decrease as the status of the group grows.

A similar relation between health and the objective economic status can be seen in case of some specific diseases, blood circulation issues in particular. The highest concentration of those who suffered myocardial infarction can be seen among the population with the lowest status, and this number of infarction occurrences goes down as long as the subjective economic status goes up (Blaxter, 1990; Wilkinson 1992; Adler, Boyce, Chesney, Folkman and Syme, 1993; Marmot, 2004).

\subsubsection{The Role of Economic Factors in Health Inequity}

The dependence of health from the objective economic status is also an illustration of the type of health issues.

First, it shows a higher concentration of people with low income among those with high or very high likelihood of health loss: groups of those unable to maintain self-care and suffering from limited physical capacity include the elderly. In other words, inverse relation between the objective economic status and the health status is mostly typical of the elderly and the oldest groups of the population, which supports the hypothesis concerning the fact that the development of a stable negative relation between health and economic status is largely subject to the factor of accumulating the negative impact from financial hardships and their consequences over a long time. Second, there is direct relation between chronic diseases and the economic status. A complementary analysis of the relation in view of the age factor among people with various incomes also shows that the poor have a higher share of those suffering from diagnosed chronic diseases in all age groups, if compared with similar age groups with the maximum income. As for acute communicable diseases both the poor and the rich are equally vulnerable to them, with the middle class demonstrating a lower level of vulnerability.

The distribution of the different age population suffering from health issues in the groups of the subjective economic status also suggests that in the young age (or in the first part of life) the share of people with detected (diagnosed) issues is growing along with the subjective economic status growth. Yet, there is a tendency seen in those approaching the end of their age: the higher subjective economic status the higher concentration of people with health issues.

People who are rather well-off have significant material possibilities to get the medical assistance needed and to take care of, and maintain their own health. This could be seen, in particular, in the prevalence of preventive visits to 
medical institutions. Among the well-off this index is significantly higher, if compared to the disadvantaged, both in general, and within specific age and level-ofeducation groups (Русинова Н. Л., Панова Л.В. Сафронов В.В., 2007; Падиарова А.Б., 2009).

Thus, there has been both direct and inverse relation identified between health and the objective and subjective economic status. On the one hand, the higher economic status the more often people visit medical institutions for preventive purposes and the higher the number of those with chronic diseases detected. On the other hand, the higher economic status the lower (on average) the number of people with health issues, the lower the share of people with severe heart diseases (myocardial infarction), and the lower the share of those with significant and stable loss of health. In general the individual findings on health support the conclusions and assumptions concerning the prolonged and ongoing impact of income on health, which were done based on the analysis of socio-economic inequity and territorial differences in people's health status. There we can see both cumulative effect where "the quantity (of money) shall transfer into quality (of health)” after a certain period of time, and the stimulating role of higher income on the ongoing health monitoring and timely response to its disturbances.

The relation between the social status and various aspects of mental issues has been of interest for both doctors and researchers since long ago; the findings from a lot of research have demonstrated the meaningfulness of social status in understanding mental diseases and disability. The epidemiological research projects conducted all over the world have shown an inverse relation between mental issues and the social class. There has been consistent data obtained suggesting that mental disturbances are more common for the lower social class. At the same time, lately there have been discovered other channels of the significant impact that inequity has on health. In particular, it has been shown that chronic stresses related to the dissatisfaction with one's socioeconomic status may result in neuro-endocrine and psychological functional alterations thus contributing to the disease likelihood. It has already become a common opinion that a longer feeling of fear, uncertainty, low selfesteem, social isolation, inability to make decisions and be in charge of the situation both at home and at work impact health seriously: this may cause depression, increase susceptibility to communicable diseases, diabetes, high blood cholesterol, and cardio-vascular issues. Low socioeconomic position, therefore, impacts health directly through deprivation and financial hardships, and through the subjective vision of one's "unequal" position in the society and the related judgment, relations, experiences. When studying the influence that the socio-economic status has on health focus should be kept on both the objective and subjective socio-economic status. Therefore, there is an undoubted connection between the financial status and health, which can be seen both from the scientific-theoretical viewpoint, and at the level of common sense (Падиарова, А.Б., 2009).

Both unemployed men and women demonstrate a higher level of alcohol or substance dependency in case they belong to the unemployed. The social class is a risk factor of death due to alcohol abuse, which is also related to such structural social factors as poverty, disadvantage position and the social class. The rate of alcohol-induced death is higher among men involved in physical labor than among clerks, yet the relative index will depend on the age. Men aged 25-39 and involved in common nonqualified physical labor demonstrate a death rate 10-20 times higher than representatives of the middle class, while among those aged 55-64 the same index is only 2,54 times higher if compared to those who are involved in a type of labor requiring special skills (Harrison \& Gardiner, 1999).

A Cambridge research into the development of minor delinquency produced data stating that unstable employment at the age of 18 was an important independent predictor of previous conviction history among young men aged 21-25 (Farrington, 1995).

The growing number of researches into the relation between poverty and health indicates that low income combined with unfavorable demographic factors and insufficient external support causes stress and life crisis, which serve risk factors for children and may trigger mental disturbances in them.

Confused, strict and full of violence upbringing as well as lack of control and poor child-parent attachment will aggravate the poverty effect and worsen other structural factors, when it comes to minor delinquency. A Cambridge research into the evolution of minor criminals poverty was taken as one of the most important predictors for delinquency (Farrington, 1995). The materials of the WHO show that social inequities may also have an impact on the level of vulnerability to environmental risks and the severity of these risks' impact on health. There have been 4 of such mechanisms demonstrated:

Mechanism 1. Social determinants correlate with the quality of the environment. Socially disadvantaged groups often live and work under poorer environmental conditions if compared to the general population.

Mechanism 2. The levels of impact are in a certain dependency on the factors related to social inequity (such as level of knowledge and type of behavior in terms of health). Therefore in case of similar environment disadvantaged groups may be subject to a more intense impact than the population in general.

Mechanism 3. Factors related to social inequities (such as health status and biological susceptibility) affect the dependency “impact - response". Given the same level of impact, disadvantaged groups may reveal a higher level of vulnerability to unfavorable consequences for health, e.g. due to synergy of various risk factors.

Mechanism 4. Social inequities have a direct impact on the end results related to health, which may reveal itself through both environmental and non-environmental mechanisms. However, under similar dependency parameters of "impact - response" disadvantaged groups may reveal a higher level of vulnerability to unfavorable consequences for health due to poorer access to the respective services and reduced capacity to cope with the negative effects. The absolute scale of the consequences can also be higher in disadvantaged groups because of higher prevalence of previously existing health issues (Whitehead and Dahlgren, 2008).

According to most researches representatives of lower socio-economic groups stand a higher vulnerability to negative environmental factors (Braubach M, Fairburn J., 2010; Bolte G, Tamburlini G, Kohlhuber M., 2010). 


\subsubsection{Gender Features of Health Inequity and the Family Role}

Research conducted all over the world show that gender is another important factor determining health inequity.

The feature typical of Russia is an extremely high death rate among men and an unprecedented gap between the life expectancy among men and women (12-14 years).

This attracts more attention to men's health in modern Russia, which overshadows the fact that, according to medical statistics and opinion polls, women have been consistently showing higher rates of health issues.

The lower status of health in Russian women - not only compared to Russian men yet also to women in other countries - is also seen from the calculations of the healthy life expectancy. According to the data provided by the leading Russian demographers the huge gap in the healthy life expectancy of the 20-year olds (both Russian men and women) and their Western counterparts (13 years), in men is due to a higher level of death rate (especially in the working age), and in women - due to a lower health status (mostly in the older age) (Масленникова Г. Я., Оганов Р. Г., 2002, 2004).

Actually, the so-called gender paradox, which could be expressed as "women become ill more often while men die earlier", which is a global tendency, typical of civilized countries at least, has always been of interest to researchers. For a long time this gender paradox has been explained by medical statistics, supporting the fact that men typically suffer from fatal illnesses and fall prey to illnesses that do not reveal well expressed symptomatology; as for women - they typically suffer from acute and chronic, even though less severe conditions.

Thus, a number of empirical research projects have shown a significant variability in the scale, and sometimes in the patterns of gender-bound health differences at various stages of life cycle, as well as within different health indicators.

\subsection{Health Inequity in Russian Federation: State of Things}

The issue of inequity in income distribution in the postsocialist area has been a subject for wide discussion both in our country and abroad. This point has always been the focus of researchers and politicians, from time to time giving raise to acute socio-political debate. Russia is no exception here given the significant changes it has undergone in the latest decade. Quite a tough issue is developing human potential under rapidly progressing market conditions and similarly rapidly disappearing social benefits for the disadvantaged. In view if this, experts define two types of challenges: on the one hand the country is facing typical of poor countries troubles like spread of communicable diseases, regions with stagnating poverty (still present in Russia), undeveloped infrastructure and high death rate. On the other hand the country is suffering from healthcare and education crisis, and such issues are common for advanced post-industrial countries as well.

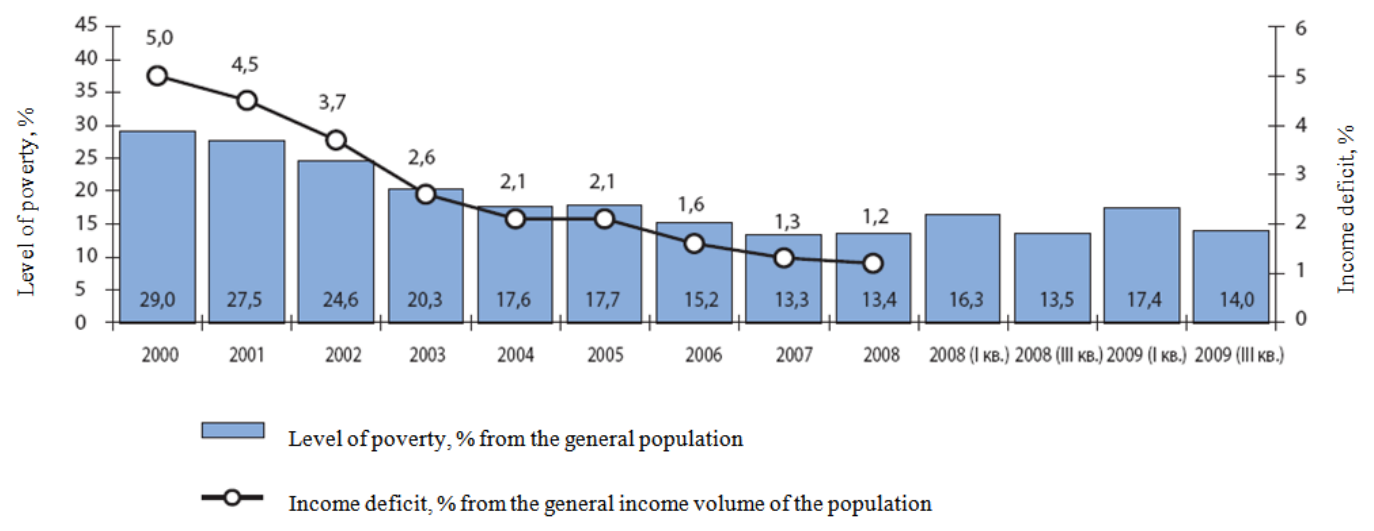

Figure 1. Level and depth of poverty in Russia 2000-2009

\subsection{Poverty Profile in Russia}

Poverty in Russia has a number of typical features. For instance, most vulnerable are families with children and, therefore, children themselves, who are under 16 . Note to be made though that this issue is not common for most countries. As for retirees they are under lower risks of being affected by poverty because most of them work and the social benefit system is oriented, first of all, at the elderly.

Special mention should be made of the fact that working population is the larger part of the poor group even despite of salary growth. In order to reduce the number of poor people among the working population the minimum salary should be at least $150 \%$ of the minimum cost of living. In the April of 2009 25\% or the working population received their salaries below this minimum. $70 \%$ of them had children. $37,4 \%$ of the working population received salaries below $200 \%$ of the minimum cost of living.

This level of pay for labor is sufficient for meeting the minimum needs of one employee and one child. Therefore, even in a situation where two parents are employed such salaries cannot be enough to support two children at the minimum level.

The largest share of the poor population is accounted for by the people who are able to work, especially youth. Countrymen are more vulnerable to poverty than urban population. Besides, the maximum poverty risk affects the unemployed population, economically inactive groups, as well as those living on social and disability benefits.

\subsection{Level of Poverty and Inequity}

The dynamics of poverty and inequity is determined by the consumption share for the $20 \%$ of poorest against the 
total volume of consumption. Up until 2000 this index was about 5,8-6,1\%. Later on the share of the poorest $20 \%$ has gone down, which serves perfect evidence of the fact that the poor have got no access to the results of economic growth.

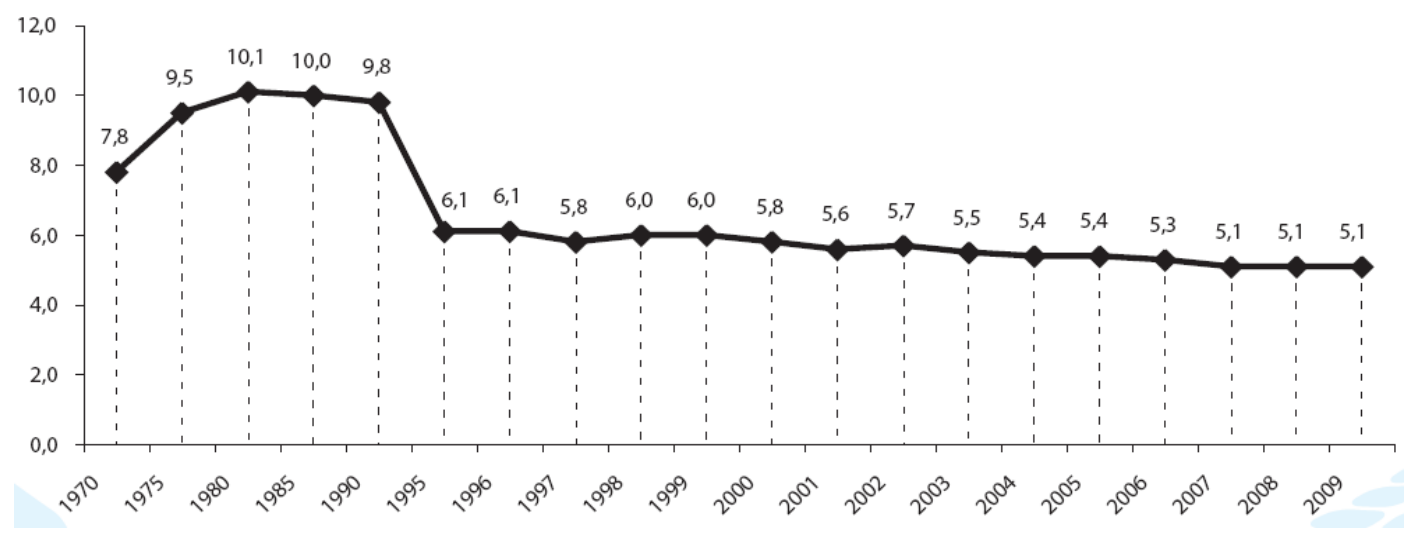

Figure 2. Income share dynamics for $20 \%$ of the poorest against the total volume of income 1970-2009, \% (The World Bank in Russia Russian Economic Report, No. 21, March 2010, http://siteresources.worldbank.org/INTRUSSIANFEDERATION/Resources/305499-1245838520910/62389851269435660465/RER21rus.pdf).

The liberal economic reforms went along with a significant fall in the standard of living and an increase in the socio-economic differentiation. The growing economic inequity has become a serious challenge both for the people and for the government. Our country now has significant inequity in terms of health and accessible medical assistance due to polarization of income and opportunities, which means limited and clearly deficient current social policy carried out in our society. The recent research findings have provided quite a clear demonstration of significant differences in people's opportunities at birth, during the preschool and school period, in terms of getting access to higher education, housing, transportation, shopping, recreation and fun activities, relationships with the state, access to medical services, life expectancy, maintaining health status and healthy lifestyles, religious affiliation, funeral services, inheritance, etc. Just 20-25 years ago when the disproportion was not so extreme some specialists in social hygiene and healthcare arrangement even talked about potential homogenous conditionality of health in our country.

We must admit that health inequity is a new and, obviously, a long-term issue in Russia. Even though there have always been differences in people's health status this point never got so much attention. One of the sources of social tension in any country is the gap between people's welfare, in the level of their prosperity. The level of prosperity is determined by two factors:

1) the size of (any kind of) property possessed by individuals;

2) the size of the individuals' income (Дашкевич П.Р., 1995; Денисов П.Р., 1997).

One of the criteria of civilization in any country's social sphere is maintaining the respective appropriate living standard for the groups (families) that for some reasons cannot meet even the minimum standards and customs (food, clothing, leisure, etc.). One of the most urgent social issues in Russia that came into being because of economic changes is unprecedented inequity in income. According to the Russian Statistics Agency (Rosstat), by 2006 the income of the most prosperous groups was 16 times the share of the least prosperous ones (Российский статистический ежегодник, Россия в цифрах, 2006).
However, if we take into account that the official statistics often underestimates the socio-economic differentiation in Russia not taking into view the shadow economy, then the true gap in question may be much larger. According to the data provided by T. Zaslavskaya (2005) the inequity gap between the $10 \%$ at the extremities is $30-40$ times. As noted at the Report on Poverty Evaluation made by the World Bank (2004), this fast growth of income inequity in Russia was close to a record - Russia here is very much different from other countries including Central and East Europe, where they also had a transfer to the market economy. The social stratification trend in our country that became especially obvious in the 1990-s is still there under the rather long process of economic growth noticed in the recent years - income differentiation was detected in 2007 as well (Щербакова E.M., 2008).

The high rate of economic and socio-structural changes in Russia that were ahead of most people's adjustment capacity brought to many increased levels of chronic stress, loss of control over life circumstances, and resulted in prevalence of behaviors related to health risks, first of all high alcohol consumption (Cockerham, 2000; Cockerham, Hinote, Abbott, 2006).

All this could not but affect Russian people's health, which is well seen from the growing death rate and reduced life expectancy.

As a result, by the early $21^{\text {st }}$ Century (2000) the death rate brought Russian into one line with African countries located south of Sahara, namely 15 deaths a year per 100 people, which is nearly double the index of developed societies (Римашевская Н.М., Кислицина О.А., 2004).

The recent years have witnessed quite clear a vicious circle where the national Russian healthcare system has found itself - the more funding is invested into specialized inpatient care and hi-tech clinics the less funding is given to prevention and early detection, which results in an increased number of patients, adds to the severity of their conditions, detection of diseases at later and even very bad untreated stages, and chronization of pathologies, which requires even more funding for tertiary healthcare.

Therefore, the modern Russian healthcare system could be described with a high level of inequity in distributing health opportunities among individuals and groups of people, as well as with a conflict between the state and the 
society, with erosion of the aims and objectives in the sphere of healthcare (Сизова И.Л., 2007).

The impact of social inequity in the Russian society has been especially seen the young generation, whose origin and development came onto the reforms.

Under the reforms in Russia, apart from traditional disturbances there have come into being new trends in youth's health: "psychization” and "psychologization” of diseases, increasing social disadaptation, loss of confidence about one's strength, increased feeling of "social loneliness". This aspect creates the necessity of a sociological reflection on the changing social conditions and their impact on new deviations in youngsters' health, and the development of new practices in certain classes and social groups.

Even though we have already discussed poverty as the most important factor of inequity, Vladimir Putin’s words - Russia is a rich country of poor people - make us turn towards the issue again, yet in the context of the Russian reality.

On the initial stage of the economic reforms in Russia the core group of the poor was traditionally represented by the so-called vulnerable groups including retirees, disabled, large families and one-parent families with children. Nowadays the focus is definitely shifting towards a different risk group - the "working" poor, the part of the society that are able to work and, due to various reasons have low income, which keeps them from supporting themselves and their families properly.

Quite often poverty has also socio-psychological preconditions. One of them is the "overtaking" poverty. This term could be used to describe a phenomenon implying prestige consumption. It is typical for youth, rather than for older people, to dress well and to look no worse than others. The things that prosperous parents' children have (fashionable and expensive clothes) set up certain example attracting children whose parents cannot afford that. If a prosperous parent can buy something never feeling and financial issue then a poor parent's budget may be seriously affected by the same purchase. This prestige consumption makes many people live beyond their financial capacity. Those from poor families feel uncomfortable due to their own position and that of their family, which does not allow them live better. This causes a generation conflict where children blame their parents for not wanting or not being able to "make money”, even despite all the morals. As a result poor people's children find illegal ways to make money, which they need to "catch up" with the rich ones, to live up to the standards imposed on them by the middle or the upper class (Падиарова А.Б., 2008, 2009).

The poor's focus is shifted towards negative evaluation of the reality, pessimism, and despair. They are often unable to build proper relations within their families high voice in the family, mutual reprimands, obscene words and abusive language become a common thing. Such conditions develop a special lifestyle and a value system, which could be described by restraint and voluntary isolation, economic and social dependency, lack of clear behavior role models, separation and political passivity, absence of future plans and self-confidence; increased disposition to conflicts in family relations (rude talks, quarrels between parents and children, frequent divorces) (Кислицина О.А., 2005).
Other reasons responsible for acute aggravation of health inequity in Russia during the transition period include:

1. Actual shift in healthcare from caring for health to clinical medicine, i.e. from mass recreational and preventive measures to individual treatment.

2. Increased share of paid services, development of new relationships with patients, which destroy the basics of medical ethics, and which make it possible to view the patient as another source of income; chronic deficit of funding with a large number of various sources of that, which never contributes to financial transparency.

3. Sharp increase in inequity in terms of people's access to medical services, while the majority of these people are socially disadvantaged.

4. Prominent inequity in doctors' incomes.

5. Unequal access to medical services for certain groups of people: homeless people, neglected children, migrants, and just financially vulnerable people.

6. Continuing practice of increasing the share of costly and expensive medicine, a huge gap between the quality and quantity of medical assistance in cities and in the provincial areas, and the gap between the assistance provided to rural and to urban residents is increasing.

7. Obvious and neglected mismatch between people need for preventive medicine, treatment and rehabilitation, and the funding allocated to the area. All this makes medicine spontaneous, paid, creates new issues and even power abuse, which may result in undermining the entire structure of the system. Since recently, instead of improving medical assistance, managers in healthcare have started talking about lifestyles, thus trying to avoid responsibility for current state of things in medicine and shifting it onto people who abuse tobacco, alcohol, stick to unhealthy diets and just do not take care of their own health, even though, actually, all this is one of the tasks for the system of healthcare.

8. Overly complexity of the very system of healthcare and, as a result, its poor controllability and efficiency (Комаров Ю.М., 2010).

Thus, we believe that in order to reduce the urgency of health inequity it takes comprehensive intersectoral measures, which should be initiated by the public health sector, while all the municipal agencies and public groups should be involved as equal partners.

Investigation into health inequity: City of Stavropol (K. R. Amlaev, 2010)

In order to avoid any average data and to receive representative information about the life quality of the most vulnerable groups of Stavropolities there was a sociological survey conducted (questionnaires) for representative sample. The total bulk of respondents was 600 people following the calculation formula for representative sample. The major purpose of the survey is to investigate issues related to health inequity.

Samples were developed by the following principle: every third visitor of the local social services was interrogated. The design of questionnaire implied the Ostfold list (Norway) for life quality evaluation, which included the following blocks

1. Assessment of one's own health.

2. Respondents' lifestyles.

3. Respondents' social activity.

4. Trust towards various authorities and social services. 
5. Satisfaction with the neighborhood of residence and with the living conditions.

6. Respondents' socio-demographic description.

The questionnaire was designed at the institutes for public health of Sweden and Norway as part of the European project Health Profile (HePro), (translated into Russian and adjustment to the purpose of the research $-\mathrm{K}$. Amlaev, 2005).

The sample bulk included both representatives of vulnerable groups and other groups as well. The filed study (71 persons) was conducted in the October of 2009. The work with large database of primary information determined the choice of methods, implementing which was possible based on the statistical software package SPSS.

\subsection{Description of Sample Bulk}

The major poll included 529 people +71 from the field study. $32,1 \%$ of them were men, $67,9 \%$ - women. The age distribution was the following way: Stavropolities under $20-8,4 \%$, 20-29 - 22,1\%, 30-39 - 21,0\%, 40-49 - 16,7\%, $50-59-15,6 \%, 60-69-9,9 \%$, over $69-6,3 \%$.

More than half of the respondents have stable employment (51,0\%). 17,0\% of the bulk are unemployed retirees. Occasional employment have $7,8 \%$ of the respondents, and temporarily employed are 6,3\%. 5,7\% are undergoing professional training, officially registered as jobless are $2,1 \%, 1,1 \%$ are supported by their parents or some other people; $1,3 \%$ are involved in other activities.

$44,5 \%$ of the respondents have a higher education degrees, $27,4 \%$ have secondary professional degrees, $5,0 \%$ are with initial professional training. 11,4\% finished 11-year schooling; 6,9\% graduated after 9 years of schooling. $4,8 \%$ of the respondents have just elementary education.

$44,4 \%$ of the respondents are officially married; $9,7 \%$ live with their partners; $25,3 \%$ are single; $11,0 \%$ are divorced; 9,5\% are widow(er)s. 11,0\% live alone; 23,9\% live with just one person at home; $28,3 \%$ - with two persons at home, $19,0 \%$ - with three, $10,5 \%$ - with four. $4,7 \%$ of the respondents have families of six, $1,4 \%$ - of seven, $0,7 \%-8$, and only $0,5 \%$ of them reside with a family of 9 .

$18,4 \%$ of the respondents have no children. Most of them $(38,0 \%)$ have only 1 child. One third of the respondents have 2 children, while the share of those raising 3 children is $9,6 \%, 4$ children $-0,8 \%$, and 5 children - 0,3\%.

$50,0 \%$ live in a separate apartment (in apartment blocks), and 28,5\% live in cottage-type houses; $8,2 \%$ rent an apartment or a room; $5,7 \%$ have a room in a dormitory; $3,6 \%$ dwell in communal apartments, $1,9 \%$ live in cottages; other types of housing have $21 \%$ of the respondents. $75,2 \%$ of them are owners of their dwellings.

The most common source of income among respondents is their salaries at the major employment (67,6\%). 34,1\% have their retirement benefits as their source of income. Relatives help to $23,0 \%$, while $21,7 \%$ get social benefits and advantages; $17,4 \%$ have extra employment. 10,7\% also grow products in their garden, which is their extra income. 9,4\% have scholarship in their income structure. $7,1 \%$ have income from entrepreneur activities, and 1,1\% have income from bank deposits, shares, and bonds; other types of income are common for $4,4 \%$ of the respondents.

$22,6 \%$ spend less than half of their income on food; $38,4 \%$ spend on food about half of their income, and $39,0 \%$ of the respondents spend on food over $50 \%$ of their income. $32,7 \%$ of the respondents often do not have enough money to buy the most essential products. $41,9 \%$ cannot afford buying things for longer use; 19,8\% do afford expensive things for longer use, yet on a loan only and not all at the same time. Those who cannot buy only an apartment or an expensive car account for $4,7 \%$, and $1 \%$ of the respondents do not restrict themselves in anything.

Here and below we provide only statistically meaningful results of the research (sample tolerance - no more than 2,0, $\mathrm{p}<0,05$, Pearson's chi-square $>20,0)$ !

\subsection{Health and Lifestyle}

$31,0 \%$ of the respondents described their health as pretty good. $40,2 \%$ out of them were under 50 , and $11,6 \%$ - over 50.

Those spending less than half of their income on food (conditionally well-off)in 21,1\% of the cases described their own health as excellent; 36,9\% of the respondents mentioned they experience frequents stresses.

Among those with stable employment 35,8\% experience stress, while among the unemployed this share was in 54,5 of the respondents.

Most often various diseases affect people over 50 and unemployed retirees (83,4\% and 89,7\% respectively). Especially indicative is the difference between those with elementary education and those holding a higher education degree $-76,0 \%$ vs $48,3 \%$.

$85,5 \%$ of widow(er)s and $45,9 \%$ of single respondents suffer from some chronic illnesses, traumas, disability, etc.

It has been found that $20,0 \%$ of those supported by their parents mentioned they constantly suffer from physical and emotional issues, while among the unemployed the same answer gave $9,1 \%$ of the respondents. From among those with elementary education 68,0\% experience negative impact of their physical and emotional state on their social activities, while those holding a higher education degree fewer people depend on physical and emotional troubles. Most often emotional issues were mentioned by the unemployed group and unemployed retirees (65,9\% and 72,7\%). Respondents with elementary education more often suffer from the impact of their mental-emotional state $-80,0 \%$.

Least time on physical activity spend migrants (40\%) and the unemployed.

$39,5 \%$ of men and $71,3 \%$ of women accounted for nonsmokers. And there were more smokers among respondents with elementary education rather than among those with higher education. Only $20 \%$ of the respondents with elementary education referred to themselves as nonsmokers while among those with a higher education degree the same was true for $66,5 \% .42,1 \%$ of single and $25,9 \%$ of those officially married smoke. Never smoked $20,0 \%$ of the respondents with elementary education and $54,7 \%$ with higher education.

$23,7 \%$ of the respondents who work occasionally tried alcohol-containing liquids that are non-consumable; 
unlike them those with stable employment tried similar liquids in $14,7 \%$ of cases only.

Single people more often non-consumable alcohols $(23,5 \%)$ while among those married officially only $9,1 \%$ tried such alcohols.

\subsection{Social Aspects}

It is interesting to note that only $4,9 \%$ of those with stable employment do not count on somebody's support and assistance. At the same time $41,5 \%$ of the respondents with only occasional jobs, and $40,0 \%$ of dependent respondents do not expect any support. Those who are employed expect somebody's support in $81,9 \%$ of cases. People taking care of a disabled child expect some support in $50,0 \%$ of cases, while only $20,0 \%$ of migrants believe someone will provide them with such support.

The research has shown that the respondents' social activity also depends on their belonging to a particular social group. It has been noted that the most politically active part of the population includes people with stable employment as only $17,9 \%$ of them do not go to the elections; however, if we speak about the dependent population and housewives, on the contrary, remain more indifferent toward elections giving negative answer to the respective question in $60,0 \%$ and $39,5 \%$ of cases.

Migrants have proven to be the least politically active group $-80,0 \%$ of them do not attend election. The most active group is retirees - only $14,2 \%$ of them gave a negative answer.

More than half of the respondents trust the system of healthcare - 53,1\%; in terms of the system of education this number was - 52,7\%; social services - 54,9\%, the police $-22,1 \%$. About $50,0 \%$ of the respondents trust job placement service - 44,3\%, while over $30 \%$ of the respondents trust social insurance services $-30,9 \%$.

The highest level of trust towards the police demonstrate war veterans - 57,2\%, while among the employed population the police enjoys trust from $27,7 \%$ only; as for migrants none of them trust the police.

$23 \%$ of the respondents trust insurance companies; the prosecution office and Court have trust from 21\% of the respondents.

A little over $20 \%$ of the respondents trust law-making authorities and about one third trust Head of the City Administration. Over one third of the respondents trust the media.

$45,9 \%$ of the respondents absolutely agree or agree rather than not that nothing depends on them. 86,4\% of those with elementary education completely agree, or quite agree that nothing depends on them. Among those with a higher education degree the same answer gave $41,7 \%$ of the respondents.

\subsection{Quality of Medical Assistance and its Availability}

$60 \%$ of the respondents are satisfied with the district doctor's working hours. The cost of treatment was acceptable for $36,5 \%$ of the respondents. Half of the respondents were happy with the attitude towards patients. $34,7 \%$ of the respondents found the quality of the treatment good.

The cost of the administered treatment was unacceptable for $50,0 \%$ of the disabled, $20,0 \%$ of migrants,
$17,1 \%$ of retirees in general, and for $13,9 \%$ of those employed. $34,0 \%$ of the respondents noted that being hospitalized in-patiently is easy or rather easy. People with temporary employment said so only in $21,0 \%$ of cases. Dependents in $100 \%$ cases believe that hospitalization in the in-patient department is difficult or rather difficult. $80,0 \%$ of migrants mentioned that it was rather difficult or difficult to be hospitalized in the inpatient ward, while among war veterans only $12,5 \%$ mentioned the same.

\subsection{Social and Daily-life Conditions}

Over $50,0 \%$ of all respondents are happy with the service offered at most shops, post offices, personal service places, etc.

$40,0 \%$ of the respondents consider sufficient the cultural opportunities (libraries, movie houses, theaters, dance clubs). A little over one third of the respondents expressed satisfaction with active leisure opportunities (stadia, swimming pools, gyms), and over $40,0 \%$ of the respondents were happy with the public transport.

$20,0 \%$ of dependent respondents are happy with the service they can get at most shops, post offices, personal service places, etc.

$25 \%$ of dependent respondents consider acceptable the opportunities for cultural life (libraries, movie houses, theaters, dance clubs), while $100 \%$ of this group of respondents found active leisure opportunities (stadia, swimming pools, gyms) insufficient.

The level of daily service was found poor by $60,0 \%$ of migrants, $50,0 \%$ of the disabled, and $35,7 \%$ of the employed respondents.

War veterans and Labor veterans are unhappy with the daily service offered at their neighborhood in 16,1\% and $12,5 \%$ of cases respectively.

Insufficient the local opportunities for cultural life were found among migrants, the disabled, retirees, and the employed - 60,0\%, 50,0\%, 43,8\%, and 39,6\% respectively. War veterans consider cultural opportunities insufficient in $14,3 \%$ of cases only.

\section{Conclusion}

The survey has proven that poverty among Stavropolities is rather high, while the crisis only exacerbated the issue. According to our findings over 39\% of the respondents spend more than half of their income on food. This correlates with percentage of those who lack money to meet their basic needs $-32,7 \%$.

Our research has shown that people's assessment of their own health depends on their marital status, income, and place of residence; it is lower in widow(er)s, lowincome groups, and those residing in the "depressed" neighborhoods.

A high level of stress has been found in the unemployed, widowers and those residing in overpopulated areas, which, as we think, is due to lack of stability, insufficient socio-psychological support, and dense population (high level of noise, traffic jams, etc.).

The unemployed and migrants pay the least attention to physical activity. An independent risk factor for tobacco and alcohol dependency is a low level of education; the 
same category of people demonstrates the highest level of alcohol consumption.

Dependent people, temporarily employed, and migrants have the lowest expectation of getting support from anyone.

The electoral activity of Stavropolities depends on their income and duration of residence in the area - low-income groups and migrants are infrequent visitors at elections. Another factor reducing electoral activity is the area of residence.

The social service that enjoys the highest demand from the residents of Stavropol is the district medical service. This service, along with the system of education, and social assistance services, enjoys most trust. A low level of trust has been found towards the police (3,7\% among the disabled and $0 \%$ - among migrants).

The level of trust to the Head of City is $27,8 \%$, which is higher than the level of trust to law-makers, prosecutors, Court, and insurance companies. The lowest trust to various bodies has been found among the dependent, migrants, and those residing in the "depressive" neighborhoods of Stavropol.

The disabled and migrants demonstrate a lower level of satisfaction with the district medical service. A low level of satisfaction with doctors' attitude has been found among the disabled and migrants, which could be attributed to deontological issues. Troubles with hospitalization experience those who are dependent, who have temporary employment, and migrants. Various types of discrimination (according to the respondents' opinion) experience people with a low level of education and those residing in communal apartments. The lowest assessment to their neighborhood of residence was given by dependents, which is due to low mobility access for this group of respondents, and residents of the "depressive" areas, which is likely to be linked to lack of an efficient transport system and a low level of social and cultural infrastructure in these areas.

Thus, despite the measures aiming at providing support to socially vulnerable groups this work proves not efficient enough.

The research has demonstrated an uneven effect and quality of the socio-economic health determinants in various groups of Stavropol's residents. The correlations detected between the impact of such determinants and the lifestyles, personal assessment of health, and the respondents' social activity, may serve a basis for making governance decisions. There has also been an intersectoral action plan developed to obtain positive results and to reduce health inequities in the residents of Stavropol.

\section{References}

[1] Амлаев К.Р. Современные подходы к формированию политики снижения неравенства в здоровье населения //А.В. Курбатов, К.Р. Амлаев, К. А. Муравьев// «Медицинский вестник Северного Кавказа. 2010.-№ 2 (22). С. 67-72.

[2] Амлаев К.Р. Роль семьи, образования, трудовой занятости и принадлежности к определенным социальным группам в формировании неравенства в здоровье/А.В. Курбатов, К.Р. Амлаев //Вестник Ставропольского государственного университета, 2011-№73 (2). С. 167-172.

[3] Амлаев К.Р. Современное состояние проблемы неравенства в здоровье: экологические, гендерные, экономические аспекты (обзор) /А.В. Курбатов, К.Р. Амлаев, К.А. Муравьев //Вестн. Ставропольского гос. ун-та. 2011. № 3. С. 24-30.

[4] Амлаев, К.Р. Состояние проблемы неравенства в здоровье в Российской Федерации /А.В. Курбатов, К.Р. Амлаев, К.А. Муравьев // "Системный анализ и управление в биомедицинских системах" 2011. Том 10 № 3. С. 602-610.

[5] Амлаев, К.Р. Профиль здоровья уязвимых групп населения города Ставрополя // К.Р. Амлаев, А. Х. Джатдоев, О. В. Рецева, М. М. Бжезовская, А.В. Курбатов, и др. // Ставрополь: Сервисшкола, 2011. 58c.

[6] Амлаев К.Р. Современное состояние проблемы неравенства в здоровье (обзор)/ Амлаев К.Р., Курбатов А.В. Профилактическая медицина №1, 2012; 10-15.

[7] Всемирный Банк в России, Доклад об Экономике России №19, Июнь 2009-[Электронный ресурс].-Электрон. дан.-Режим доступа:

http://siteresources.worldbank.org/INTRUSSIANFEDERATION/ Resources/305499-1245838520910/rer19-rus.pdf

[8] Всемирный Банк в России, Доклад об Экономике России №21, Март 2010-[Электронный ресурс].-Электрон. дан.-Режим доступа:

http://siteresources.worldbank.org/INTRUSSIANFEDERATION/ Resources/305499-1245838520910/62389851269435660465/RER21rus.pdf

[9] Вишневский, А. Смертность в России: главные группы риска и приоритеты действия / А. Вишневский, В. Школьников // Науч. докл.-М.: Моск. Центр Карнеги, 1997. Вып. 19. 84с.

[10] Дашкевич, П. Р. Неравенство распределения дохода как фактор экономического роста в некоторых переходных странах / П. Р. Дашкевич.-М.: ЮНИТИ, 1995 С.17-23.

[11] Денисов, П. Р. Социальное расслоение общества: причины, последствия и меры по ограничению / П. Р. Денисов // Экономист. 1997.-№ 1.-С.73-82.

[12] Журавлева, И. В. Здоровье подростков в социоструктурном контексте / И. В. Журавлева // Социальное расслоение и социальная мобильность.-М.: Наука, 1999. С. 124-143.

[13] Журавлева, И. В. Отношение к здоровью индивида и общества / И. В. Журавлева.-М.: Наука, 2006238 с.

[14] Кислицина, О. А. Неравенство в распределении доходов и здоровья в современной России / О. А. Кислицина.-М.: РИЦ ИСЭПН, 2005.-С. 2-17.

[15] Комаров, Ю. М. Общественное здравоохранение в России: прошлое, настоящее и будущее [Электронный ресурс] / Ю. М. Комаров.-Электрон. дан.-05.03.2010.-Режим доступа: http://ochirova.viperson.ru/wind.php?ID=621732\&soch=1.

[16] Масленникова, Г. Я. Влияние курения на здоровье населения: место России в Европе / Г. Я. Масленникова, Р. Г. Оганов // Профилактика заболеваний и укрепл. здоровья. 2002. № 6.-С. 17-20.

[17] Медицинские и социально-экономические потери, обусловленные курением мужского населения России / Г. Я Масленникова [и др.] // Профилактика заболеваний и укрепл. здоровья. 2004. № 3.-С. 5-9.

[18] Муздыбаев, К. Качество жизни населения Петербурга: 1990 2004 годы / К. Муздыбаев.-СПб.: ГУП МЦСЭИ «Леонтьевский центр», 2005.- 225 с.

[19] Назарова, И. Б. Здоровье занятого населения / И. Б. Назарова.М.: МАКС Пресс, 2007.- 526 с.

[20] Назарова, И. Б. Здоровье российского населения: факторы и характеристики (90-е годы) / И. Б. Назарова // СОЦИС.-2003.№ 11.-С. 57-69.

[21] Неравенство и смертность в России / под ред. В. Школьникова, Е. Андреева, Т. Малеевой.-М.: Моск. Центр Карнеги, 2000.- 107 с.

[22] Падиарова, А. Б. Здоровье как жизненный ресурс и реальная ценность нового поколения россиян / А. Б. Падиарова // Россия и мир: история, культура, регионоведение: сб. науч. тр. / под ред. С. В. Осипова, Т. В. Петуховой.-Ульяновск: УлГТУ, 2008.-С. 191-196.

[23] Падиарова, А. Б. Здоровье как ценность в общественном мнении молодежи / А. Б. Падиарова // Корпоративная культура: от теории к практике: сб. науч. тр.-Ульяновск: УлГТУ, 2009.-С. 86-89.

[24] Падиарова, А. Б. Корпоративная целостность ВУЗа как фактор социального здоровья нового поколения россиян / А. Б. Падиарова // Корпоративная культура: от теории к практике: сб. науч. тр.-Ульяновск: УлГТУ, 2008.-С. 67-73. 
[25] Падиарова, А. Б. Социальное неравенство в факторной модели здоровья молодых россиян / А. Б. Падиарова // Вестн. Поволжской Акад. Гос. Службы.-2009.-№ 2.-С. 36-43.

[26] Падиарова, А. Б. Социальное неравенство как фактор здоровья нового поколения россиян / А. Б. Падиарова // Известия высш. учеб. заведения. Поволжский регион. Общественные науки.-2009.-№ 1.-С. 2-12.

[27] Падиарова, А. Б. Социальные аспекты управления здоровьем молодых россиян / А. Б. Падиарова // XXXIV Гагаринские чтения: науч. тр. Междунар. молодежной науч. конф. В 8 т. / отв. ред. Н. И. Сердюк.-М.: МАТИ, 2008.-Т.7.-С. 237-238.

[28] Римашевская, Н. Неравенство доходов и здоровье / Н. Римашевская, О. Кислицина // Народонаселение.-2004.-№ 2.С. 5-17.

[29] Русинова, Н. Л. Продолжительность жизни в регионах России: значение экономических факторов и социальной среды / Н. Л. Русинова, Л. В. Панова, В. В. Сафронов // Журн. социологии и социальной антропологии.-2007.-№ 1.-С. 140-161.

[30] Русинова, Н. Л. Социальное неравенство и здоровье в СанктПетербурге: Ответственность и контроль над здоровьем / Н. Русинова, Дж. Браун // Журн. социологии и социальной антропологии.-1999.-№ 1.-С. 103-114.

[31] Русинова, Н. Л. Социально-статусные группы: различия в субъективном здоровье / Н. Русинова, Дж. Браун // Петербургская социология.-1997.-№ 1.-С. 38-59.

[32] Сизова, И. Л. Социальное неравенство шансов на здоровье нормы справедливости и государственная политика в области здравоохранения: экстраполяции / И. Л. Сизова // Вклад НКО в реформу социальной сферы: улучшение здоровья населения, внедрение инклюзивного образования и жилищная реформа: материалы интернет-конф. Информ.-аналитического портала SocPolitika.ru., 2007.

[33] Тапилина. Социально-экономические различия и неравенства / Тапилина // СОЦИС.-2004.-№ 3.-С. 126-137.

[34] Щербакова, Е. Дифференциация денежных доходов выросла [Электронный ресурс] / Е. Щербакова // Демоскоп [Электрон. журн.].-2008.-№ 321.-С. 322.-Режим доступа: http://demoscope.ru/weekly/2008/0321/ barom02.php.

[35] Anand, S. Inequality and Development: A Critique / S. Anand, S. M. R. Kanbur // Journal of Development Economics.-1993.-JVb 41.-P. 19-43.

[36] Anand, S. The Concern for Equity in Health / S. Anand // J. of Epidemiology and Community Health.-2002.-Vol. 56, № 7.-P. 485-487.

[37] Blaxter, Mildred. Health and Lifestyles / Mildred Blaxter.-London: Tavistock ; New York: Routledge, 1990.-211 p.

[38] Bolte, G. Environmental inequalities among children in Europeevaluation of scientific evidence and policy implications / G. Bolte, G. Tamburlini, M. Kohlhuber // Eur. J. of Public Health.-2010.Vol. 20, № 1.-P. 14-20.

[39] Braubach, M. Social inequities in environmental risks associated with housing and residential location-a review of evidence / $\mathrm{M}$.
Braubach, J. Fairburn // Eur. J. of Public Health.-2010.-Vol. 20, № 1.-P. 36-42.

[40] Braveman, P. World Health Report 2000: how it removes equity from the agenda for public health monitoring and policy / P. Braveman, B. Starfield, Geiger H. Jack // BMJ.-2001.-№ 323.-P. 678-680.

[41] Braveman, P., E. Pitarino, A. Creese, and N. Monash. Equity in Health and Health Care: A WHO/SIDA Initiative. WHO/ARA/96.1./ P. Braveman [et al.].-Geneva: World Health Organization. 1996.-32 p.

[42] Cockerham, William C. Health Lifestyles in Russia / William C. Cockerham // Social Science and Medicine.-2000.-Vol. 51, issue 9.-P. 1313-1324.

[43] Cockerham, William C. Psychological Distress, Gender, and Health Lifestyles in Belarus, Kazakhstan, Russia, and Ukraine / William C. Cockerham, P. Hinote Brian, Pamela Abbott // Social Science and Medicine.-2006.-Vol. 63, issue 9.-P. 2381-2394.

[44] Cockerham, William C. The Social Determinants of the Decline of Life Expectancy in Russia and Eastern Europe: A Lifestyle Explanation / William C. Cockerham // J. of Health and Social Behavior.-1997.-Vol. 38, issue 2.-P. 117-130.

[45] Farrington, D. P. The development of offending and antisocial behaviour from childhood: key finding from the Cambridge Study in Delinquent Development / D. P. Farrington // J. of Child Psychology and Psychiatry.-1995.-Vol. 36.-P. 929-964.

[46] Harrison, L. Do the rich really die young? Alcohol-related mortality and social class in Great Britain, 1988-94 / L. Harrison, E. Gardiner // Addiction.-1999.-Vol. 94.-P. 1871-1880.

[47] Kunst, Anton E. Measuring Socioeconomic Inequalities in Health / Anton E. Kunst, Johan P. Mackenbach.-Copenhagen: World health organization regional office for Europe, 1994-115 p.

[48] Mackenbach, Johan P. Measuring the Magnitude of SocioEconomic Inequalities in Health: An Overview of Available Measures Illustrated with Two Examples from Europe / Johan P. Mackenbach, Anton E. Kunst // Social Science and Medicine.1997.-Vol. 44, № 6.-P. 757-771.

[49] Marmot, M. Income and health: material and psychosocial pathways. A reply to Lynch et al. / M. Marmot, R. G. Wilkinson // BMJ.-2001.-№ 2, suppl. 322.-P. 1233-1236.

[50] Marmot, Michael. The Status Syndrome: How Social Standing Affects Our Health and Longevity / Michael Marmot.-New York: Times Books, Henry Holt and Company, 2004-336 p.

[51] Whitehead, М. Концепция и принципы преодоления социального неравенства в отношении здоровья. Восходящее выравнивание. Ч. 1. [Электронный ресурс] / M. Whitehead, G. Dahlgren.-Электрон. дан.-Копенгаген: Европейское региональное бюро ВОЗ, 2008.-41 стр.-Режим доступа: http://www.euro.who.int/document/e89383r.pdf.

[52] Wilkinson, Richard G. Income Distribution and Life-Expectancy / Richard G. Wilkinson // British Medical Journal.-1992.-№ 304.-P. 165-168.

[53] World Health Organization. Targets for Health for All.Copenhagen: WHO Regional Office for Europe, 1990.-P. 12-26. 